\title{
Impact of radiotherapy on anorectal function in patients with rectal cancer following a watch and wait programme
}

\author{
Citation for published version (APA):
}

van der Sande, M. E., Hupkens, B. J. P., Berbee, M., van Kuijk, S. M. J., Maas, M., Melenhorst, J., Beets, G. L., \& Breukink, S. O. (2019). Impact of radiotherapy on anorectal function in patients with rectal cancer following a watch and wait programme. Radiotherapy and Oncology, 132, 79-84. https://doi.org/10.1016/j.radonc.2018.11.017

Document status and date:

Published: 01/03/2019

DOI:

10.1016/j.radonc.2018.11.017

Document Version:

Publisher's PDF, also known as Version of record

\section{Document license:}

Taverne

Please check the document version of this publication:

- A submitted manuscript is the version of the article upon submission and before peer-review. There can be important differences between the submitted version and the official published version of record.

People interested in the research are advised to contact the author for the final version of the publication, or visit the DOI to the publisher's website.

- The final author version and the galley proof are versions of the publication after peer review.

- The final published version features the final layout of the paper including the volume, issue and page numbers.

Link to publication

\footnotetext{
General rights rights.

- You may freely distribute the URL identifying the publication in the public portal. please follow below link for the End User Agreement:

www.umlib.nl/taverne-license

Take down policy

If you believe that this document breaches copyright please contact us at:

repository@maastrichtuniversity.nl

providing details and we will investigate your claim.
}

Copyright and moral rights for the publications made accessible in the public portal are retained by the authors and/or other copyright owners and it is a condition of accessing publications that users recognise and abide by the legal requirements associated with these

- Users may download and print one copy of any publication from the public portal for the purpose of private study or research.

- You may not further distribute the material or use it for any profit-making activity or commercial gain

If the publication is distributed under the terms of Article $25 \mathrm{fa}$ of the Dutch Copyright Act, indicated by the "Taverne" license above, 
Original Article

\title{
Impact of radiotherapy on anorectal function in patients with rectal cancer following a watch and wait programme
}

\author{
Marit E. van der Sande ${ }^{a}$, Britt J.P. Hupkens ${ }^{\text {b,c,d }}$, Maaike Berbée ${ }^{\mathrm{e}}$, Sander M.J. van Kuijk ${ }^{\mathrm{f}}$, Monique Maas ${ }^{\mathrm{g}}$, \\ Jarno Melenhorst ${ }^{\mathrm{b}}$, Geerard L. Beets ${ }^{\mathrm{a}, \mathrm{d}}$, Stéphanie O. Breukink ${ }^{\mathrm{b}, *}$

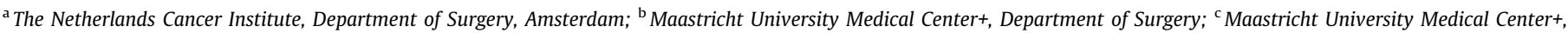

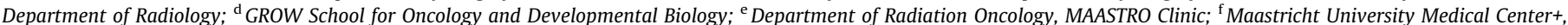 \\ Department of Clinical Epidemiology and Medical Technology Assessment; and ${ }^{\mathrm{g}}$ The Netherlands Cancer Institute, Department of Radiology, Amsterdam, the Netherlands
}

\section{A R T I C L E I N F O}

Article history:

Received 31 August 2018

Received in revised form 19 November 2018

Accepted 25 November 2018

Available online 21 December 2018

Keywords:

Rectal cancer

Radiotherapy

Functional outcome

Watch-and-wait

\begin{abstract}
A B S T R A C T
Background and purpose: To assess the long-term anorectal function in rectal cancer patients following a watch-and-wait policy after chemoradiotherapy and to investigate the dose-volume effects of radiotherapy on the anorectal function.

Methods and materials: Thirty-three patients with primary rectal cancer who were treated with chemoradiotherapy and a watch-and-wait policy with minimum follow-up of 2 years were included. We assessed the anorectal function using anorectal manometry and patient reported outcomes (Vaizey and LARS score). Dose-volume histograms were calculated for the rectum and anal sphincter complex, and associations between the dose-volume parameters and anorectal function were assessed.

Results: $\mathrm{D}_{\text {mean }}$ to the rectum and anal sphincter complex was $50.5 \mathrm{~Gy}$ and $44.7 \mathrm{~Gy}$, respectively. After a median follow-up of 38 (range 23-116) months, 33.3\% of the patients reported major LARS. Mean LARS score was $23.4 \pm 11.3$ and mean Vaizey score was $4.3 \pm 4.1$. The most frequent complaints were clustering of defaecation and faecal urgency. Trends towards a higher Vaizey and LARS score after higher anal sphincter complex dose were observed, although these associations were not statistically significant. Conclusions: This is the first study to investigate the late dose-volume effects of radiotherapy specifically on the anorectal function in rectal cancer patients. One-third of the patients had major LARS and the most frequent reported complaints were clustering and faecal urgency. Additionally, we observed trends towards worse long-term anorectal function after higher anal sphincter complex radiotherapy dose. However, this should be evaluated on a larger scale. Future efforts to minimise the dose to the sphincters could possibly reduce the impact of radiotherapy on the anorectal function.
\end{abstract}

(C) 2018 Elsevier B.V. All rights reserved. Radiotherapy and Oncology 132 (2019) 79-84
The standard of care for patients with locally advanced or distal rectal cancer is neoadjuvant chemoradiation therapy (CRT) followed by total mesorectal excision (TME). CRT leads to downsizing and downstaging of the tumour in most patients, it may increase the opportunity for sphincter-saving surgery and CRT decreases the risk for local recurrence [1]. However, treatment with neoadjuvant CRT and TME can adversely affect bladder, sexual, and anorectal function in the long term [2]. In patients who achieve a complete response to neoadjuvant CRT, a watch-and-wait policy can be considered to avoid the related morbidity and mortality of TME [3-5].

The main goal of a watch-and-wait policy is an anticipated improved functional outcome and quality of life, while maintaining

* Corresponding author at: Maastricht University Medical Center+, Department of Surgery, P. Debyelaan 25, PO Box 5800, 6202 AZ Maastricht, the Netherlands.

E-mail address: s.breukink@mumc.nl (S.O. Breukink). a good oncological outcome. While there is growing evidence supporting the oncological safety, the quality of life and functional outcomes after a watch-and-wait policy remain less explored. In a previous report [6] we showed that quality of life after a watch-and-wait policy was better than after CRT and TME. Nonetheless, the anorectal function was impaired in the watchand-wait group, with one third of the patients reporting major bowel dysfunction. This comes as no surprise as irradiation of the rectum is known to cause injury to the rectal wall and related autonomic nerves resulting in impaired long-term functional outcome [7]. Because of the proximity of the anal canal to the tumour, the anal sphincter muscles are often also in the high-dose field of radiation in patients with low rectal cancer. However, very limited data are available on the relationship between radiotherapy dose and anorectal dysfunction in rectal cancer patients. Particularly in rectal cancer patients in whom no resection is performed after CRT, e.g. in patients following a watch-and-wait policy, the effects 
of chemoradiotherapy alone on functional outcomes can be assessed. In this study we assessed the long-term anorectal function in rectal cancer patients following a watch-and-wait policy, using the Vaizey score, LARS (Low Anterior Resection Syndrome) score and anorectal manometry. Additionally, we explored the associations between the radiotherapy dosimetric parameters of the rectum and anal sphincter complex and the anorectal function outcomes.

\section{Methods and material}

\section{Study population}

Patients with primary rectal cancer and a complete response after CRT who were treated according to a watch-and-wait policy in our institute between January 2009 and April 2015 and who had a minimum follow-up of two years were included in this cross-sectional study. Follow-up of $\geq$ two years was chosen so long-term effects, which at that time are expected to have reached a plateau phase, could be measured. All patients were part of a prospective cohort study on the watch-and-wait policy (clinicaltrials.gov NCT00939666) and a part was also included in a previous report on quality of life [6]. The inclusion criteria for a watchand-wait policy in rectal cancer have been described previously $[4,8]$. Exclusion criteria for the present study were salvage therapy for recurrent disease or having a colostomy. Ethics committee approval was obtained for sending out questionnaires and patients gave a separate informed consent for a manometric evaluation of the anorectal function during routine follow-up.

\section{Chemoradiotherapy}

All patients were treated with chemoradiotherapy. 3Dconformal or intensity-modulated radiotherapy consisted of $50.4 \mathrm{~Gy}$, with daily fractions of $1.8 \mathrm{~Gy}$ on weekdays. Dose specification occurred according to ICRU 50/62. The clinical target volume (CTV) included the gross tumour volume, the mesorectum, presacral and internal iliac node regions, and in case of distal node positive tumours the obturator fossa. A symmetric PTV margin of $1 \mathrm{~cm}$ was applied. No dose limitations were used for the anal sphincter complex during initial treatment planning. Radiotherapy was combined with $825 \mathrm{mg} / \mathrm{m}^{2} /$ day capecitabine bid, seven days a week.

\section{Organ delineation and dose calculations}

The rectum and anal sphincter complex were manually delineated on the axial CT images ( $3 \mathrm{~mm}$ slice thickness) of the original radiotherapy planning CT scans, using Focal ${ }^{\mathrm{TM}}$ treatment planning system (XiO, Elekta AB, Stockholm, Sweden). Organ contours were defined according to the Pelvic Normal Tissue contouring guidelines by the Radiation Therapy Oncology Group (RTOG) [9]. The rectum was defined as a solid organ including the rectal contents from the lowest slice with a rectal lumen to the rectosigmoid flexure where the rectum moves ventrally and loses its round shape. The anal sphincter complex (internal and external sphincter muscle) circumference was delineated as a solid organ from anal verge to the anorectal border. All delineations were performed by one investigator (M.S.) and confirmed by a radiation oncologist specialised in rectal cancer treatment (M.B.). Examples of these delineations are shown in Fig. 1.

Dose-volume histograms (DVH) were calculated with the original treatment plans and were used to measure the radiation dosimetric coverage of the rectum and anal sphincter complex for each patient. The maximum and mean doses were calculated

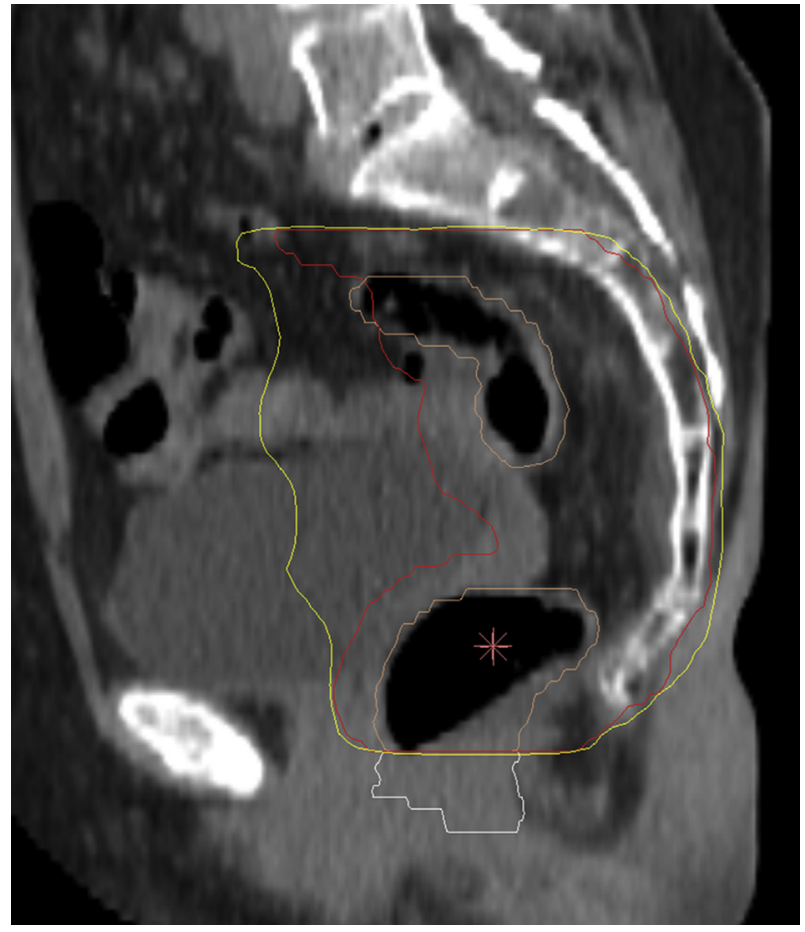

Fig. 1. Delineation of anal sphincter complex (white) and rectum (orange) on CT scan. (For interpretation of the references to colour in this figure legend, the reader is referred to the web version of this article.)

$\left(D_{\max }\right.$ and $\left.D_{\text {mean }}\right)$, as well as the relative volumes receiving a dose of 30-50 Gy or more $\left(\mathrm{V}_{30 \mathrm{~Gy}}-\mathrm{V}_{50 \mathrm{~Gy}}\right)$.

\section{Manometry}

Anorectal function was assessed using manometry at one of the routine follow-up outpatient visits. Anorectal manometry was performed with the patient in the left lateral position with knees and hips bent to $90^{\circ}$. Patients did not receive bowel preparation [10]. A four-channel catheter (Mui Scientific, Mississauga, Canada) with a water perfusion system connected to an electronic polygraph (Synectics Medical, Stockholm, Sweden) was used for the investigation. A $7 \mathrm{~cm}$ inflatable balloon was incorporated at the top of the catheter. The catheter was calibrated outside the patient at study level before introduction. A stationary technique was used and mean anal resting pressure (MRP) and squeeze anal pressures (MRP) were measured [11]. These parameters were calculated as the average of the four radial measuring points. For rectal capacity, first rectal sensation (FS), volume at first urge to defaecate (FUTD) and maximum tolerable volume (MTV) were measured during stepwise balloon inflation. Manometry examinations were performed by two investigators (M.S. and B.H.).

\section{Questionnaires}

Anorectal function was also evaluated using two validated scores sent out as questionnaires: the Vaizey score and LARS score.

The Vaizey score was used to assess faecal incontinence [12]. Patients were asked to evaluate their defaecation pattern in the last four weeks, including questions regarding consistency of stool loss, frequency and its effect on lifestyle. Results are reported on a continuous scale from 0 to 24 . Faecal incontinence is defined as a score $\geq 12$ points.

The Dutch version of the LARS score was used to evaluate bowel dysfunction [13]. It consists of five questions regarding incontinence for flatus and liquid stool, frequency, clustering and urgency. 
The range of this score is 0-42 and outcome categories are no LARS (score 0-20), minor LARS (score 21-29) and major LARS (score 30-42).

\section{Statistical analysis}

SPSS v22.0 (SPSS Inc, Chicago, IL) was used for statistical analyses. Stochastic regression imputation was used to impute incomplete variables to prevent a loss of statistical precision and to decrease the likelihood of bias. Multiple regression was used to quantify preliminary associations between the dose-volume parameters and the manometry and questionnaire scores and was adjusted for sex, tumour height and age. A two-tailed $p$ value $\leq 0.05$ was considered significant in all analyses.

\section{Results}

\section{Patient characteristics and dosimetric data}

Thirty-three patients with a median age of 68 (range 38-85) years, of whom 21 male (64\%), were included in this study. Patients' demographics are shown in Table 1. Median time from end of CRT to anorectal function assessment was 38 (range 23$117)$ months. Twenty-three patients (70\%) had low rectal cancer ( $\leq 5 \mathrm{~cm}$ from anorectal junction), 10 patients had mid-high rectal cancer. Mean $( \pm S D)$ distance from distal border of tumour to anorectal junction was $3.9( \pm 3.0) \mathrm{cm}$.

The radiation dose-volume data are shown in Table 2 . The mean $( \pm S D) D_{\text {mean }}$ and mean $V_{50 \text { Gy }}$ to the rectum were $50.5 \pm 1.3 \mathrm{~Gy}$ and $90.1 \pm 19.4 \%$, respectively. The mean $( \pm S D) D_{\text {mean }}$ to the anal sphincter complex was $44.7 \pm 9.7 \mathrm{~Gy}$, whereas the $V_{50 \text { Gy }}$ was $47.1 \% \pm 37.9 \%$, meaning that on average $47 \%$ of the anal sphincter volume had a planned dose of $\geq 50 \mathrm{~Gy}$.

\section{Manometry}

Overall, the mean MRP was $30 \pm 12 \mathrm{mmHg}$ and mean MSP was $104 \pm 41 \mathrm{mmHg}$. Mean volume at first sensation (FS) was $47 \pm 26 \mathrm{~mL}, 88 \pm 28 \mathrm{~mL}$ at first urge to defaecate (FUTD), and $136 \pm 36 \mathrm{~mL}$ at maximum threshold (MTV), see Table 3 .

\section{Questionnaire outcomes}

The mean Vaizey score was $4.3 \pm 4.1$. Two (6\%) patients had faecal incontinence, based on the Vaizey score ( $>12$ points). The results for all items on the Vaizey score are presented in Table 4. Of the 33 patients, 15 (46\%) patients reported a lack of the ability to defer defaecation for 15 minutes. One (3\%) patient reported the use of pads/plugs, and one (3.0\%) other patient reported the use of constipating agents.

The mean LARS score was $23.4 \pm 11.3$. Twelve (36\%) patients had no LARS (score 0-20), 10 (30\%) patients had minor LARS (score 21-29) and 11 (33\%) patients had major LARS (score 30-39). The most reported complaint in the LARS questionnaire was clustering, with nine (27\%) patients reporting clustering at least once a week and 18 patients (55\%) less than once a week. Urge incontinence for faeces at least once a week was reported by 15 (46\%) patients and less than once a week by 9 (27\%) patients. Occasions of uncontrollable flatus at least once a week were reported in 10 (30\%) patients, less than one a week in 8 (24\%) patients. Complaints of frequency or accidental leakage of stools were less often reported, see Fig. 2.

\section{Correlation of dosimetric data to anorectal function}

There weren't any statistically significant associations between dose parameters and the LARS or Vaizey score. However, we did observe a trend towards higher Vaizey scores after higher $D_{\max }(\beta=0.341, p=0.211), V_{30 G y}(\beta=0.374, p=0.095), \quad V_{35 G y}$
Table 1

Patients' demographics $(n=33)$.

\begin{tabular}{ll}
\hline Characteristics & \\
\hline Sex & $21(63.6 \%)$ \\
Male & $12(36.4 \%)$ \\
Female & $67.5(38-85)$ \\
Median age, in years (range) & $38.4(23-117)$ \\
Median follow-up, in months (range) & \\
cT stage & $8(24.2 \%)$ \\
cT2 & $24(72.8 \%)$ \\
cT3 & $1(3.0 \%)$ \\
cT4 & \\
cN0 stage & $8(24.2 \%)$ \\
cN1 & $12(36.4 \%)$ \\
cN2 & $13(39.4 \%)$ \\
Tumour height & \\
$\leq 5 \mathrm{~cm}$ & $23(69.7 \%)$ \\
$>5$ cm & $10(30.3 \%)$ \\
\hline
\end{tabular}

Table 2

Radiation dose-volume data.

\begin{tabular}{lll}
\hline & Anal sphincter complex & Rectum \\
\hline${\text { Volume }\left(\mathrm{cm}^{3}\right)}_{\mathrm{D}_{\max }(\mathrm{Gy})}$ & $14.9 \pm 4.7$ & $98.0 \pm 27.7$ \\
$\mathrm{D}_{\text {mean }}(\mathrm{Gy})$ & $47 \pm 11$ & $52.0 \pm 1.1$ \\
$\mathrm{~V}_{30}$ Gy $(\%)$ & $44.7 \pm 9.7$ & $50.5 \pm 1.3$ \\
$\mathrm{~V}_{35}$ Gy $(\%)$ & $85.4 \pm 25.3$ & $99.2 \pm 2.7$ \\
$\mathrm{~V}_{40}$ Gy $(\%)$ & $85.0 \pm 25.6$ & $98.8 \pm 2.8$ \\
$\mathrm{~V}_{45}$ Gy $(\%)$ & $81.3 \pm 27.2$ & $99.1 \pm 2.7$ \\
$\mathrm{~V}_{50}$ Gy $(\%)$ & $80.3 \pm 28.4$ & $99.0 \pm 3.1$ \\
\hline
\end{tabular}

Abbreviations: $\mathrm{D}_{\max }=$ Maximal dose, $\mathrm{D}_{\text {mean }}=$ Mean dose,

$\mathrm{V}_{30 \mathrm{~Gy}}-\mathrm{V}_{50 \mathrm{~Gy}}=$ percentage of volume receiving $>30$ to $>50 \mathrm{~Gy}$.

( $\beta=0.343, p=0.126)$ and $\mathrm{V}_{40 \mathrm{~Gy}}(\beta=0.381, p=0.109)$ of the anal sphincter complex. Additionally, a trend towards higher LARS scores after higher $D_{\text {mean }}$ of the anal sphincter complex ( $\beta=0.362, p=0.122$ ) was observed. Regarding the rectal dose, regression analysis showed trends towards higher Vaizey scores after higher $\mathrm{V}_{35 \mathrm{~Gy}}(\beta=0.353, p=0.066)$ and $\mathrm{V}_{40 \mathrm{~Gy}}(\beta=0.309$, $p=0.117$ ), although not statistically significant. The results of all regression analyses are presented in Appendix 1.

For all dosimetric parameters of the anal sphincter complex, except $V_{50}$ Gy, higher doses were associated with higher squeeze pressure (MSP). No associations were found between the dosimetric parameters and resting pressure (MRP) or anorectal sensory function (FS, FUTD, MTV).

\section{Discussion}

This study assessed the long-term anorectal function and the association between the anorectal function and the radiotherapy dose parameters in rectal cancer patients following a watch-andwait policy. One-third of the patients has major LARS after a minimal follow-up of two years. The most frequent complaints were clustering of defaecation and faecal urgency. Additionally, we observed trends towards worse long-term anorectal function after higher anal sphincter complex radiotherapy dose.

To date, there have been few studies that assessed the anorectal function in rectal cancer patients treated according to a watchand-wait policy after CRT. In our previous study by Hupkens et al. [6], the long-term quality of life and functional outcomes were compared between 41 watch-and-wait patients and 41 patients treated with CRT and TME. In that study, $36 \%$ of the 
Table 3

Vaizey score items $(n=33)$.

\begin{tabular}{|c|c|c|c|c|c|}
\hline & Never & Rarely & Sometimes & Weekly & Daily \\
\hline Incontinence for solid stool, $n(\%)$ & $28(85)$ & $-(0)$ & $4(12)$ & $-(0)$ & $1(3)$ \\
\hline Incontinence for liquid stool, $n(\%)$ & $21(64)$ & $7(21)$ & $4(12)$ & $1(3)$ & $-(0)$ \\
\hline Incontinence for gas, $n(\%)$ & $13(40)$ & $11(33)$ & $5(15)$ & $1(3)$ & $3(9)$ \\
\hline \multirow[t]{2}{*}{ Alterations in lifestyle, $n(\%)$} & $27(81)$ & $3(10)$ & $2(6)$ & $-(0)$ & $1(3)$ \\
\hline & No & Yes & & & \\
\hline Need to wear a pad/plug, $n(\%)$ & $32(97)$ & $1(3)$ & & & \\
\hline Use of constipating agents, $n(\%)$ & $32(97)$ & $1(3)$ & & & \\
\hline Unable to defer defaecation for $15 \mathrm{~min}, n(\%)$ & $17(54)$ & $15(46)$ & & & \\
\hline
\end{tabular}

Table 4

Results of anorectal manometry.

\begin{tabular}{ll}
\hline & $n=33$ \\
\hline MRP, mean (SD) mmHg & $30(12)$ \\
MSP, mean (SD), mmHg & $104(41)$ \\
FS, mean (SD), mL & $47(26)$ \\
FUTD, mean (SD), mL & $88(28)$ \\
MTV, mean (SD), mL & $136(36)$ \\
\hline Abbreviations:
\end{tabular}

Abbreviations: $\quad \mathrm{MRP}=$ mean resting pressure, $\mathrm{MSP}=$ mean squeeze pressure, $\mathrm{FS}=$ volume to first sensation, FUTD = volume to first urge to defecate, $\mathrm{MTV}=$ maximum tolerable volume.

watch-and-wait policy patients experienced major LARS, compared to $67 \%$ of the patients who underwent CRT followed by TME. This showed that although bowel function was generally better after a watch-and-wait policy, there were patients with significant functional impairment after CRT alone.

Habr-Gama et al. on the other hand concluded that the consequences of radiotherapy on the anorectal function may be minimal [14]. The anorectal function of patients undergoing watch-andwait after CRT to was compared to the function of patients treated with full-thickness local excision after CRT. Fifty-four watch-andwait patients were assessed with anorectal manometry and validated questionnaires and most outcomes were considered to be within the normal range. However, the Fecal Incontinence Quality of Life (FIQL) Scale and the Vaizey score were used, which both emphasise on faecal incontinence. Although faecal incontinence is a common issue, bowel dysfunction after rectal cancer treatment is more complex and may also involve frequent bowel movements and complaints of clustering and faecal urgency [15]. The scores used in the study of Habr-Gama et al. may not have been sensitive enough to detect these complaints adequately and may therefore have underestimated the adverse effects of radiotherapy.

Despite an absence of baseline anorectal function information in the present study, it is likely that neoadjuvant chemotherapy contributed to the observed bowel dysfunction in this study population as it is well known that neoadjuvant radiotherapy is a risk factor for anorectal dysfunction after TME [16-18]. In other pelvic malignancies, however, it is better established what the effects of stand-alone radiotherapy are on bowel functioning. In anal cancer, approximately $43-54 \%$ of the patients report faecal incontinence after radiation treatment [19-21]. In prostate cancer patients, faecal incontinence is reported in up to 57\% and bowel urgency in 34\% $[22,23]$.

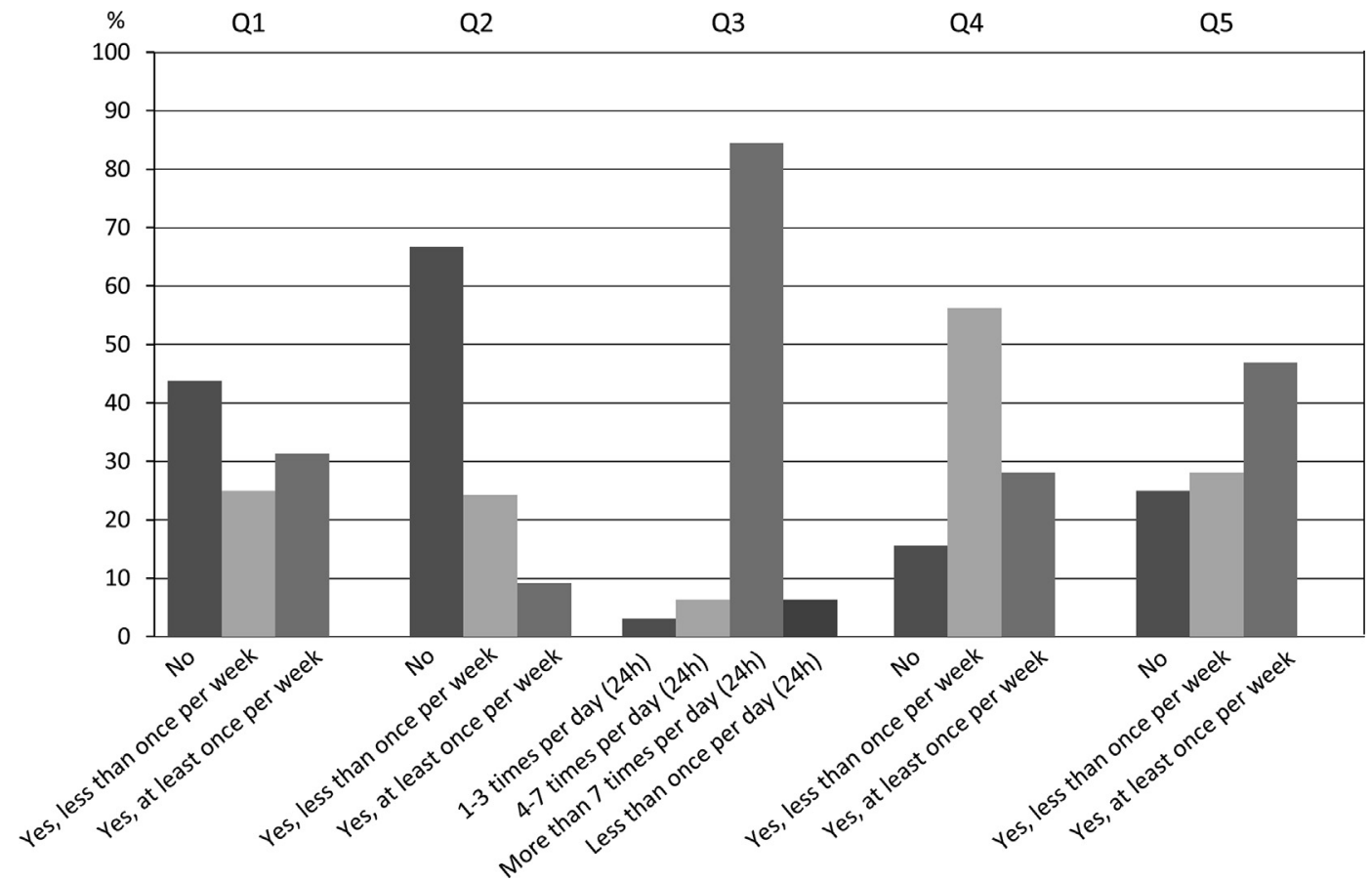

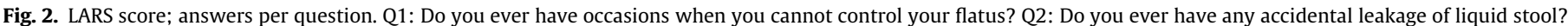

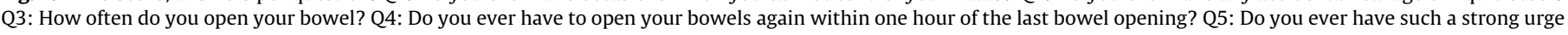
to open your bowels that you have to rush to the toilet? 
Faecal continence is a complex system and multiple components fundamental to continence are suggested to be involved in the pathogenesis of radiotherapy induced anorectal dysfunction. Some studies suggest that radiotherapy negatively affects innervation of the anorectum, including the pudendal nerve, the myenteric plexus, and the lumbosacral plexus [24-26]. Furthermore radiotherapy can induce structural morphologic alterations, such as collagen depositions in the internal and external anal sphincter $[25,27]$, and fibrosis of the rectal wall [28]. This can compromise sphincter tone, sphincter contractibility, and anorectal sensitivity.

Although we did not find an association between higher planned radiotherapy dose to the anal sphincter complex and lower anal pressures, we did observe low mean anal resting pressures and anal squeeze pressures after CRT in the present study when compared to normal values from literature [29]. This is in accordance with other studies showing reduced anal sphincter tone and squeeze pressures after pelvic irradiation [30-32]. Decreased anal pressures have been related to complaints of urgency and incontinence specifically $[33,34]$. In prostate cancer, decreased sensory thresholds for defaecation urge have also been reported after irradiation, while in the present study these were in the normal range [30,35].

While there were no significant associations between the dose parameters and questionnaire outcomes, the results suggest that higher Vaizey and LARS score were associated with a higher $D_{\text {mean }}$ and $\mathrm{D}_{\max }$ of the anal sphincter complex, and a higher LARS score with higher $D_{\text {mean }}$ of the rectum. One other study in rectal cancer survivors, treated with CRT and TME, investigated the relationship between radiation dose and anorectal function [36]. They showed that the volume of the anal sphincters receiving $>20 \mathrm{~Gy}$ was predictive of poor sphincter control as measured on the Wexner scale. In prostate cancer survivors, it has repeatedly been shown that dosimetric parameters of the anal sphincter and rectum are associated with late gastro-intestinal toxicity and patient reported outcomes [37-39]. Moreover, the dose to different anatomic substrates have been correlated to different symptoms $[33,40]$. These studies [33,37-40] suggest that the anorectal region should be avoided whenever possible during radiation treatment planning for prostate cancer. Delineation guidelines and dose constraints for the anal sphincter complex could also facilitate sphincter sparing radiotherapy in rectal cancer, and thereby possibly reduce the impact on functional outcomes.

The following limitations should be taken into consideration when interpreting the results of the present study. Our analyses are based on a relatively small group of patients. As a result, we observed several associations that may be of clinical relevance, but lacked the statistical power to draw firm conclusions. Furthermore, we had no baseline information about the anorectal function, and it remains unclear whether the reported symptoms were present before the diagnosis of rectal cancer and treatment with CRT. However, when baseline measurements are taken in rectal cancer patients, these measurements are likely to be influenced by the rectal tumour and may not represent normal anorectal functioning. In the absence of questionnaires that have been validated specifically for patients undergoing a watch-and-wait policy, we used the LARS score to assess bowel dysfunction.

Despite these limitations, this is the first study to explore the specific dose-volume effects of chemoradiation alone in rectal cancer patients on the long-term anorectal function. Our results may provide support in the rationale for sphincter sparing radiotherapy, however the relation between the dosimetric parameters and the long-term anorectal function in chemoradiation for rectal cancer should be evaluated on a larger scale. Especially with the current interest in radiotherapy to achieve organ preservation in rectal cancer, insights into functional deterioration after radiotherapy are needed, as well as insights into the specific mechanisms that are affected. With these insights, further improvements in radiotherapy delivery could be aided, as to maximise the effect on the tumour while minimising the detrimental impact on the anorectal function.

In conclusion, it is often difficult to differentiate between the radiation and surgery induced damage in rectal cancer patients treated with chemoradiotherapy. This study in rectal cancer patients followed in a watch-and-wait programme is the first study to investigate the dose-volume effects of radiotherapy specifically on the anorectal function in rectal cancer patients. One third of the patients reported major LARS after a minimal follow-up of two years. The most frequent complaints were clustering of defaecation and faecal urgency. Additionally, we observed trends towards worse long-term anorectal function after higher anal sphincter complex radiotherapy dose. However, this should be evaluated on a larger scale. Future efforts to minimise the dose to the sphincters could possibly reduce the impact of radiotherapy on the anorectal function.

\section{Conflicts of interest}

All authors had no conflicts of interests.

\section{Appendix A. Supplementary data}

Supplementary data to this article can be found online at https://doi.org/10.1016/j.radonc.2018.11.017.

\section{References}

[1] Sauer R, Becker H, Hohenberger W, Rodel C, Wittekind C, Fietkau R, et al. Preoperative versus postoperative chemoradiotherapy for rectal cancer. New England J Med 2004;351:1731-40.

[2] Jayne DG, Brown JM, Thorpe H, Walker J, Quirke P, Guillou PJ. Bladder and sexual function following resection for rectal cancer in a randomized clinical trial of laparoscopic versus open technique. Br J Surg 2005;92:1124-32.

[3] Habr-Gama A, Perez RO, Nadalin W, Sabbaga J, Ribeiro Jr U, Silva e Sousa Jr AH, et al. Operative versus nonoperative treatment for stage 0 distal rectal cancer following chemoradiation therapy: long-term results. Ann Surg 2004;240:711-7. discussion 7-8.

[4] Maas M, Beets-Tan RG, Lambregts DM, Lammering G, Nelemans PJ, Engelen $\mathrm{SM}$, et al. Wait-and-see policy for clinical complete responders after chemoradiation for rectal cancer. J Clin Oncol: Official J Am Soc Clin Oncol 2011;29:4633-40.

[5] Dossa F, Chesney TR, Acuna SA, Baxter NN. A watch-and-wait approach for locally advanced rectal cancer after a clinical complete response following neoadjuvant chemoradiation: a systematic review and meta-analysis. Lancet Gastroenterol Hepatol 2017;2:501-13.

[6] Hupkens BJP, Martens MH, Stoot JH, Berbee M, Melenhorst J, Beets-Tan RG, et al. Quality of life in rectal cancer patients after chemoradiation: watch-andwait policy versus standard resection - a matched-controlled study. Dis Colon Rectum 2017;60:1032-40.

[7] Petersen S, Jongen J, Petersen C, Sailer M. Radiation-induced sequelae affecting the continence organ: incidence, pathogenesis, and treatment. Dis Colon Rectum 2007;50:1466-74.

[8] Martens MH, Maas M, Heijnen LA, Lambregts DM, Leijtens JW, Stassen LP, et al. Long-term outcome of an organ preservation program after neoadjuvant treatment for rectal cancer. J Natl Cancer Inst 2016;108.

[9] Gay HA, Barthold HJ, O'Meara E, Bosch WR, El Naqa I, Al-Lozi R, et al. Pelvic normal tissue contouring guidelines for radiation therapy: a Radiation Therapy Oncology Group consensus panel atlas. Int J Radiat Oncol Biol Phys 2012;83: e353-62.

[10] Eckardt VF, Elmer T. Reliability of anal pressure measurements. Dis Colon Rectum 1991;34:72-7.

[11] Rao C, Sun Myint A, Athanasiou T, Faiz O, Martin AP, Collins B, et al. Avoiding radical surgery in elderly patients with rectal cancer is cost-effective. Dis Colon Rectum 2017;60:30-42.

[12] Vaizey CJ, Carapeti E, Cahill JA, Kamm MA. Prospective comparison of faecal incontinence grading systems. Gut 1999;44:77-80.

[13] Emmertsen KJ, Laurberg S. Low anterior resection syndrome score: development and validation of a symptom-based scoring system for bowel dysfunction after low anterior resection for rectal cancer. Ann Surg 2012;255:922-8.

[14] Habr-Gama A, Lynn PB, Jorge JM, Sao Juliao GP, Proscurshim I, Gama-Rodrigues $\mathrm{J}$, et al. Impact of organ-preserving strategies on anorectal function in patients 
with distal rectal cancer following neoadjuvant chemoradiation. Dis Colon Rectum 2016:59:264-9.

[15] Emmertsen KJ, Laurberg S. Rectal Cancer Function Study G. Impact of bowel dysfunction on quality of life after sphincter-preserving resection for rectal cancer. Br J Surg 2013;100:1377-87.

[16] Bregendahl S, Emmertsen KJ, Lous J, Laurberg S. Bowel dysfunction after low anterior resection with and without neoadjuvant therapy for rectal cancer: a population-based cross-sectional study. Colorectal Dis: The Official J Assoc Coloproctology Great Britain and Ireland 2013;15:1130-9.

[17] Peeters KC, van de Velde CJ, Leer JW, Martijn H, Junggeburt JM, Kranenbarg EK, et al. Late side effects of short-course preoperative radiotherapy combined with total mesorectal excision for rectal cancer: increased bowel dysfunction in irradiated patients-a Dutch colorectal cancer group study. J Clin Oncol: Official J Am Soc Clin Oncol 2005;23:6199-206.

[18] Beppu N, Kimura H, Matsubara N, Tomita N, Yanagi H, Yamanaka N. Long-term functional outcomes of total mesorectal excision following chemoradiotherapy for lower rectal cancer: stapled anastomosis versus intersphincteric resection. Digestive Surg 2016;33:33-42.

[19] Sunesen KG, Norgaard M, Lundby L, Havsteen H, Buntzen S, Thorlacius-Ussing $\mathrm{O}$, et al. Long-term anorectal, urinary and sexual dysfunction causing distress after radiotherapy for anal cancer: a Danish multicentre cross-sectional questionnaire study. Colorectal Dis: The Official J Assoc Coloproctology Great Britain and Ireland 2015:17(11):0230-9.

[20] Bentzen AG, Guren MG, Vonen B, Wanderas EH, Frykholm G, Wilsgaard T, et al. Faecal incontinence after chemoradiotherapy in anal cancer survivors: longterm results of a national cohort. Radiother Oncol: J Eur Soc Therap Radiol Oncol 2013;108:55-60.

[21] Vordermark D, Sailer M, Flentje M, Thiede A, Kolbl O. Curative-intent radiation therapy in anal carcinoma: quality of life and sphincter function. Radiother Oncol: J Eur Soc Therap Radiol Oncol 1999;52:239-43.

[22] Maeda Y, Hoyer M, Lundby L, Norton C. Faecal incontinence following radiotherapy for prostate cancer: a systematic review. Radiother Oncol: J Eur Soc Therap Radiol Oncol 2011;98:145-53.

[23] Resnick MJ, Koyama T, Fan KH, Albertsen PC, Goodman M, Hamilton AS, et al. Long-term functional outcomes after treatment for localized prostate cancer. N Engl J Med 2013;368:436-45.

[24] Yeoh EE, Botten R, Di Matteo A, Tippett M, Hutton J, Fraser R, et al. Pudendal nerve injury impairs anorectal function and health related quality of life measures $>\mid=2$ years after 3D conformal radiotherapy for prostate cancer. Acta Oncol 2017:1-9.

[25] Da Silva GM, Berho M, Wexner SD, Efron J, Weiss EG, Nogueras JJ, et al. Histologic analysis of the irradiated anal sphincter. Dis Colon Rectum 2003;46:1492-7.

[26] Lorenzi B, Brading AF, Martellucci J, Cetta F, Mortensen NJ. Short-term effects of neoadjuvant chemoradiotherapy on internal anal sphincter function: a human in vitro study. Dis Colon Rectum 2012;55:465-72.
[27] Zhu X, Lou Z, Gong H, Meng R, Hao L, Zhang W. Influence of neoadjuvant chemoradiotherapy on the anal sphincter: ultrastructural damage may be critical. Int J Colorectal Dis 2016;31:1427-30.

[28] Chen FC, Mackay JR, Woods RJ, Collopy BT, Fink RJ, Guiney MJ. Early experience with postoperative adjuvant chemoradiation for rectal carcinoma: focus on morbidity. Aust N Z J Surg. 1995;65:732-6.

[29] Gundling F, Seidl H, Scalercio N, Schmidt T, Schepp W, Pehl C. Influence of gender and age on anorectal function: normal values from anorectal manometry in a large caucasian population. Digestion 2010;81:207-13.

[30] Berndtsson I, Lennernas B, Hulten L. Anorectal function after modern conformal radiation therapy for prostate cancer: a pilot study. Tech Coloproctol 2002;6:101-4.

[31] Yeoh EK, Russo A, Botten R, Fraser R, Roos D, Penniment M, et al. Acute effects of therapeutic irradiation for prostatic carcinoma on anorectal function. Gu $1998 ; 43: 123-7$

[32] Bregendahl S, Emmertsen KJ, Fassov J, Krogh K, Zhao J, Gregersen H, et al. Neorectal hyposensitivity after neoadjuvant therapy for rectal cancer. Radioth Oncol: J Eur Soc Therap Radiol Oncol 2013;108:331-6.

33] Smeenk RJ, Hopman WP, Hoffmann AL van Lin EN, Kaanders JH. Differences in radiation dosimetry and anorectal function testing imply that anorectal symptoms may arise from different anatomic substrates. Int J Radiat Onco Biol Phys 2012;82:145-52.

[34] Krol R, Smeenk RJ, van Lin EN, Yeoh EE, Hopman WP. Systematic review: ana and rectal changes after radiotherapy for prostate cancer. Int J Colorectal Dis 2014;29:273-83.

35] Yeoh EE, Holloway RH, Fraser RJ, Botten RJ, Di Matteo AC, Moore JW, et al. Anorectal dysfunction increases with time following radiation therapy for carcinoma of the prostate. Am J Gastroenterol 2004;99:361-9.

[36] Arias F, Eito C, Asin G, Mora I, Cambra K, Maneru F, et al. Fecal incontinence and radiation dose on anal sphincter in patients with locally advanced rectal cancer (LARC) treated with preoperative chemoradiotherapy: a retrospective single-institutional study. Clin Transl Oncol 2017;19:969-75.

[37] Vordermark D, Schwab M, Ness-Dourdoumas R, Sailer M, Flentje M, Koelbl O. Association of anorectal dose-volume histograms and impaired fecal continence after 3D conformal radiotherapy for carcinoma of the prostate. Radiother Oncol: J Eur Soc Therap Radiol Oncol 2003;69:209-14.

[38] Peeters ST, Lebesque JV, Heemsbergen WD, van Putten WL, Slot A, Dielwart $\mathrm{MF}$, et al. Localized volume effects for late rectal and anal toxicity after radiotherapy for prostate cancer. Int J Radiat Oncol Biol Phys 2006;64 1151-61.

[39] Buettner F, Gulliford SL, Webb S, Sydes MR, Dearnaley DP, Partridge M. The dose-response of the anal sphincter region-an analysis of data from the MRC RT01 trial. Radiother Oncol: J Eur Soc Therap Radiol Oncol 2012;103:347-52.

[40] Smeenk RJ, Hoffmann AL, Hopman WP, van Lin EN, Kaanders JH. Dose-effect relationships for individual pelvic floor muscles and anorectal complaints after prostate radiotherapy. Int J Radiat Oncol Biol Phys 2012;83:636-44. 